\title{
Research on the Effect of Diferential Organic Fertilization of Cauliflower Hybrids Grown in Open Field
}

\author{
Alexandru Ioan APAHIDEAN ${ }^{1 *}$, Gheorghiţa $\mathrm{HOZA}^{2}$, Maria DINU ${ }^{3}$ \\ ${ }^{1}$ Department of Horticulture, University of Agricultural Sciences And Veterinary Medicine, \\ 3 Mănăștur St., Cluj-Napoca, Romania \\ ${ }^{2}$ Department of Horticulture, University of Agronomic Sciences and Veterinary Medicine, 59 Mărăști \\ Boulevard, 011464 Bucuresti, Romania \\ ${ }^{3}$ Department of Horticulture, University of Craiova 13 Alexandru Ioan Cuza St., 200585 Craiova, Romania \\ *Corresponding author, e-mail: alexandru.apahidean@usamvcluj.ro
}

Bulletin UASVM Horticulture 74(2)/ 2017

Print ISSN 1843-5254, Electronic ISSN 1843-5394

DOI:10.15835/buasvmcn-hort: 0017

\begin{abstract}
Use of manufactured fertilizers has been increasingly incorporated into regular farming practice in EU since its introduction in mid to late nineteenth century. In 2014, mineral fertilizer consumption in EU was 18 million tons. Given intensive use of fertilizers and pesticides, horticulture and vegetable growing are considered to be major contributors to some existing environmental impacts, such as water and soil pollution. Therefore farmers need to be aware and use only necessary amount of fertilizer for good plant development and to obtain high productions and to move from classical fertilization to organic fertilization. Cauliflower is not a pretentious culture but applying fertilizers can have a beneficial effect on production. Experience was carried out in 2016 in Apahida village, near Cluj-Napoca. It followed the effects of differentiated organic fertilization on three cauliflower hybrids: 'Casper' $\mathrm{F}_{1}$, 'Cercy' F1and 'Charlot' $F_{1}$. Experiment was carried out in open field and was started with seedlings. Experimental factors were: hybrid and number of fertilizations. Each experimental factor had three graduations which combined resulted in a number of nine variants. During vegetation period, growth measurements were made and also the specific technology for autumn grown cauliflower in open field was applied.
\end{abstract}

Keywords: cauliflower, hybrid, fertilization, growth measurements, production

\section{INTRODUCTION}

In Apahida area, near Cluj-Napoca there are a lot farmers that grow brassicas, in particular cabbage and cauliflower. It is important to introduce brassicas in people's diet because of the positive influence on the human body. Cruciferous vegetables contain fibers that help digestion but more importantly isothiocyanates that have anticancer effect by inhibiting the formation of tumors (Gherghi et al., 2002). The consumption of cauliflower can prevent the following types of cancer: breast, colorectal, ovarian, prostate, lung cancer (Mohanty and Srivastava, 2002) and especially the gastrointestinal form (Prohens and
Nuez, 2008). In our country there is a high demand for fresh local produced vegetables because a big quantity of the vegetables found in stores in Romania are brought from other countries (Apahidean and Apahidean, 2016). In order to fill this need, the cultivated acreage should be increased, new hybrids that are more productive should be used, and crops should be fertilized properly, for maximum results. Fertilizing agricultural soils is one of the most expensive agricultural practices, although its economic return is usually higher due to its effects on productivity, product uniformity and quality (Singh et al., 2006). Fertilizers are essential to sustaining 
vegetable production, increasing the yield and improving soil characteristics. However, when the quantity of the nutrients applied exceeds the plant's nutritional requirements, there is a higher risk of nutrient losses from agricultural soils into the ground and surface water. The resulting higher concentration of nutrients can severely deplete the ecosystems (Quirós et al., 2014). In this context, the paper shows an analysis on the influence of organic fertilizer and the number of fertilization on the production of autumn cauliflower grown in open field.

\section{MATERIALS AND METHODS}

The experiment was conducted in Apahida, Cluj County, located between $46^{\circ} 09^{\prime}$ and $47^{\circ} 00^{\prime}$ parallels, north latitude and $23^{\circ} 55^{\prime}$ and $25^{\circ} 14^{\prime}$ meridians, west longitude, has a harmonious landscape. Average annual temperatures are between $8-10.1^{\circ} \mathrm{C}$ in plateau and hilly areas, generally the summer months are warm. During the growing season (June-October 2016) monthly average temperature was between $15.3-17.3^{\circ} \mathrm{C}$. Rainfall distribution was uneven across Cluj County, with average values of $550 \mathrm{~mm} /$ year in the plain part of the county, gradually increasing towards the mountains to values of $1000-1200$ $\mathrm{mm} /$ year. Rainfall is lower in the cold season and abundant in spring and autumn. Average monthly rainfall during the growing season ranged from 16.6 to $21.3 \mathrm{~mm}$.

For this experiment three cauliflower hybrids were used. 'Casper' $F_{1}$ is a versatile hybrid, used for spring and autumn cultures. It has a vegetation period of 85-90 days and leaves protect the inflorescences very well. The average weight is between 2.5-3 and it is great for industrialization.

Another hybrid was 'Cercy' $\mathrm{F}_{1}$, which is also versatile with a vegetation period of 90-95 days. The inflorescence has an average weight of 1.8-2.5 $\mathrm{kg}$ and leaves offer a good inflorescence protection. During summer, blossoms are not sensitive to direct sunlight. Third hybrid was 'Charlot' $\mathrm{F}_{1}$. It is a new hybrid that gives great results in autumn cultures. The vegetation period is between 75 and 85 days, with an average inflorescence weight of $2-2.5 \mathrm{~kg}$. Leafs protect the inflorescences very well.

Organic fertilizer Fulet $\left(3 \mathrm{~N}-6 \mathrm{P}_{2} \mathrm{O}_{5}-12 \mathrm{~K}_{2} \mathrm{O}\right.$ $+4 \mathrm{MgO}$ ) was used for this experiment. Content of this fertilizer is total nitrogen $(\mathrm{N}) 3 \%$, phosphorus pentaoxide $\left(\mathrm{P}_{2} \mathrm{O}_{5}\right) 6 \%$, potassium oxide $\left(\mathrm{K}_{2} \mathrm{O}\right)$
$12 \%$, magnesium oxide soluble in water $(\mathrm{MgO})$ $4 \%$, calcium oxide ( $\mathrm{CaO}$ ) 3.3\%, micro-elements $0.5 \%$, organic carbon (C) $30 \%$, humidity 7 , organic substances 51\%, pH 7 (http://www.klastorf.ro).

Fertilization was applied in different ways, some variants weren't fertilized, others where fertilized once with $1 \mathrm{t} / \mathrm{ha}$ of Fulet and the other variants where fertilized twice with 1t/ha of Fulet.

By combining the two experimental factors, a number of nine variants were obtained which were located in three repetitions.

V1 - hybrid Casper F1, fertilizer not applied;

V2 - hybrid Casper F1, fertilized once with 1 t/ha of Fulet;

V3 - hybrid Casper F1, fertilized twice with $1 \mathrm{t} /$ ha Fulet;

V4 - hybrid Cercy F1, fertilizer not applied;

V5 - hybrid Cercy F1, fertilized once with with 1

t/ha Fulet;

V6 - hybrid Cercy F1, fertilized twice with with 1

t/ha Fulet;

V7 - hybrid Charlot F1, fertilizer not applied;

V8 - hybrid Charlot F1, fertilized once with 1 t/ha

Fulet;

V9 - hybrid Charlot F1, fertilized twice with $1 \mathrm{t} /$ ha Fulet.

Research was established in 2016, near ClujNapoca, in Apahida village, $46^{\circ} 48^{\prime} 28^{\prime \prime} \mathrm{N}$ latitude and $23^{\circ} 44^{\prime} 24^{\prime \prime}$ E longitude. Situated along Someș riverbed, soil is loamy, good for vegetable growing. In that area the soil is very suitable for vegetable growing. In order to obtain the seedling, seeding was done in the middle of June in alveolar trays. The substrate used was made only of peat TS3. The seedlings were planted in 19.07.2016. Planting was done mechanized, at a distance of 50 $\mathrm{cm}$ between plants and $70 \mathrm{~cm}$ between rows. The resulting density was $28000 \mathrm{pl} / \mathrm{ha}$.

During the vegetation period observations set in the experimental protocol, were made and the specific technology for autumn grown cauliflower in open field was applied.

Harvesting began on October 5 and it was done by hand.

\section{RESULTS AND DISCUSSIONS}

Growth and development of cauliflower plants were influenced by the studied factors. Regarding stem diameter, it was between $25 \mathrm{~mm}$ and 31.5 $\mathrm{mm}$ (Tab. 1). Low stem diameter was recorded at 
Tab. 1. Plant growth and development before harvesting (averages)

\begin{tabular}{cccccc}
\hline Variant & $\begin{array}{c}\text { Stem } \\
\text { diameter } \\
(\mathrm{mm})\end{array}$ & $\begin{array}{c}\text { Rosette } \\
\text { diameter } \\
(\mathrm{cm})\end{array}$ & $\begin{array}{c}\text { Leaf } \\
\text { number }\end{array}$ & $\begin{array}{c}\text { Plant height } \\
(\mathrm{cm})\end{array}$ & $\begin{array}{c}\text { Inflorescence } \\
\text { Diameter } \\
(\mathrm{cm})\end{array}$ \\
\hline V1 & 25.0 & 14.0 & 12 & 35.0 & 16.0 \\
\hline V2 & 27.0 & 16.0 & 14 & 36.5 & 18.0 \\
\hline V3 & 28.5 & 18.0 & 14 & 38.0 & 19.0 \\
\hline V4 & 26.0 & 15.0 & 13 & 36.0 & 15.5 \\
\hline V5 & 28.5 & 17.5 & 14 & 37.5 & 17.0 \\
\hline V6 & 30.0 & 19.5 & 15 & 38.5 & 19.5 \\
\hline V7 & 26.5 & 15.5 & 14 & 36.5 & 17.0 \\
\hline V8 & 29.6 & 18.6 & 15 & 38.5 & 19.5 \\
\hline V9 & 31.5 & 19.5 & 16 & 40.0 & 21.0 \\
\hline
\end{tabular}

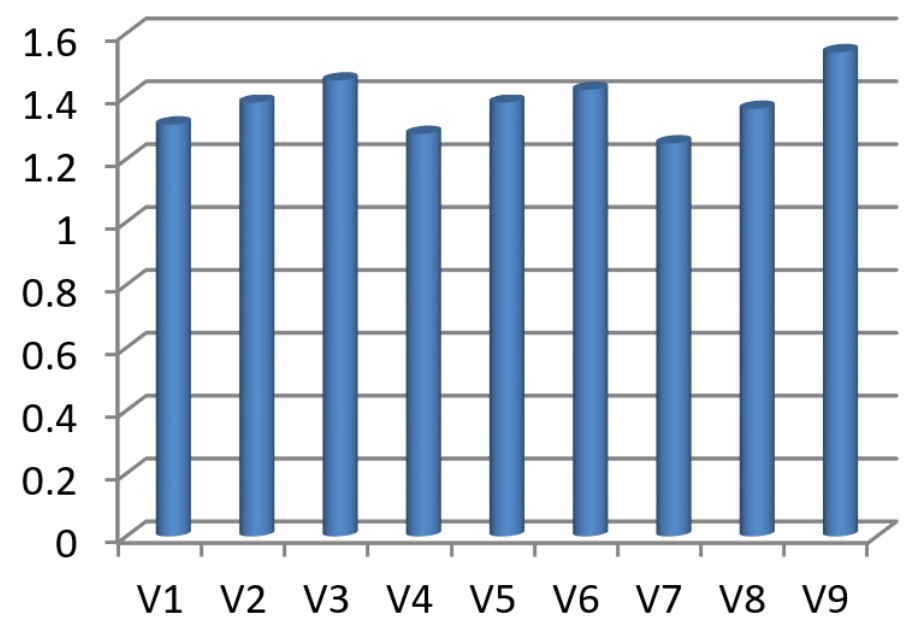

Fig. 1. Average weight of cauliflower inflorescence $(\mathrm{kg})$

'Casper' $\mathrm{F}_{1}$, unfertilized (V1) and the larger stem diameter was at 'Charlot' $\mathrm{F}_{1}$, fertilized twice (V9).

In terms of leaves rosette diameter, the lowest value was achieved at 'Casper' $\mathrm{F}_{1}$, unfertilized (V1), and the highest values were recorded at 'Charlot' $F_{1}$ (V9), and 'Cerci' $F_{1}$ (V6), that were fertilized twice.

In terms of the number of leaves found on plant, 'Casper' $F_{1}$, unfertilized (V1), had the lowest number of leaves, 12 . On the other hand 'Charlot' $\mathrm{F}_{1}$ ' fertilized twice (V9) had a highest number of leaves, 16. These values are similar to those obtained by Bianco et al. (2015) at autumn cauliflower varieties. Number of leafs also increased under different fertilizations options and it was between $13 \mathrm{~cm}$ at the unfertilized variant and $16 \mathrm{~cm}$ at the fertilized variant. Plant height varied between 31,2 at the unfertilized variant and $37,5 \mathrm{~cm}$ at the fertilized variant (Bianco et al., 2015).
Regarding plant height, it varies between 35 $\mathrm{cm}$ at 'Casper' F1, unfertilized (V1) and the highest value $40 \mathrm{~cm}$, was recorded at 'Charlot' $\mathrm{F}_{1}$ fertilized twice (V9).

Cauliflower cultivars showed significant variation in inflorescences diameter. Inflorescence diameter was influenced by the experimental factors, thus the largest diameter was $21 \mathrm{~cm}$ at 'Charlot' $\mathrm{F}_{1}$, fertilized twice (V9) and the smallest diameter, of $15,5 \mathrm{~cm}$ was obtained at 'Cerci' $\mathrm{F}_{1}$, unfertilized. Also a small inflorescence diameter was recorded at 'Casper' $\mathrm{F}_{1}$, unfertilized, of $16 \mathrm{~cm}$. Similar inflorescences diameter values (between $18 \mathrm{~cm}$ and 21,5) were obtained by Filho et al. (2015) in an experiment where they fertilized autumn cauliflower crops with doses of 244 and $320 \mathrm{~kg} / \mathrm{ha}$ of $\mathrm{P}_{2} \mathrm{O}_{5}$.

Higher inflorescence diameter was recorded $(25.64 \mathrm{~cm})$ when a dose of $320 \mathrm{~kg} / \mathrm{ha}$ of NPK was 
Tab. 2. Unilateral influence of fertilization on the production of cauliflower grown in open field

\begin{tabular}{|c|c|c|c|c|}
\hline \multirow[b]{2}{*}{ Variant } & \multicolumn{2}{|c|}{ Production } & \multirow{2}{*}{$\begin{array}{c}\text { The difference } \\
\text { compared to } \\
\text { control (t/ha) }\end{array}$} & \multirow[b]{2}{*}{ Significance } \\
\hline & $\left(\mathrm{kg} / \mathrm{m}^{2}\right)$ & $(\%)$ & & \\
\hline $\begin{array}{l}\text { Unfertilized } \\
\text { (control) }\end{array}$ & 3.59 & 100.0 & 0.00 & - \\
\hline $\begin{array}{c}\text { Fertilized once } \\
\text { with } 1 \mathrm{t} / \mathrm{ha} \\
\text { Fulet }\end{array}$ & 3.85 & 107.2 & 0.26 & $* *$ \\
\hline $\begin{array}{c}\text { Fertilized twice } \\
\text { with } 1 \mathrm{t} / \mathrm{ha} \\
\text { Fulet }\end{array}$ & 4.12 & 114.7 & 0.53 & $* * *$ \\
\hline $\begin{array}{l}\text { LSD (p 5\%) } \\
\text { LSD (p 1\%) } \\
\text { LSD (p } 0.1 \%)\end{array}$ & & $\begin{array}{l}0.15 \\
0.24 \\
0.45\end{array}$ & & \\
\hline
\end{tabular}

Tab. 3. Hybrid influence upon production

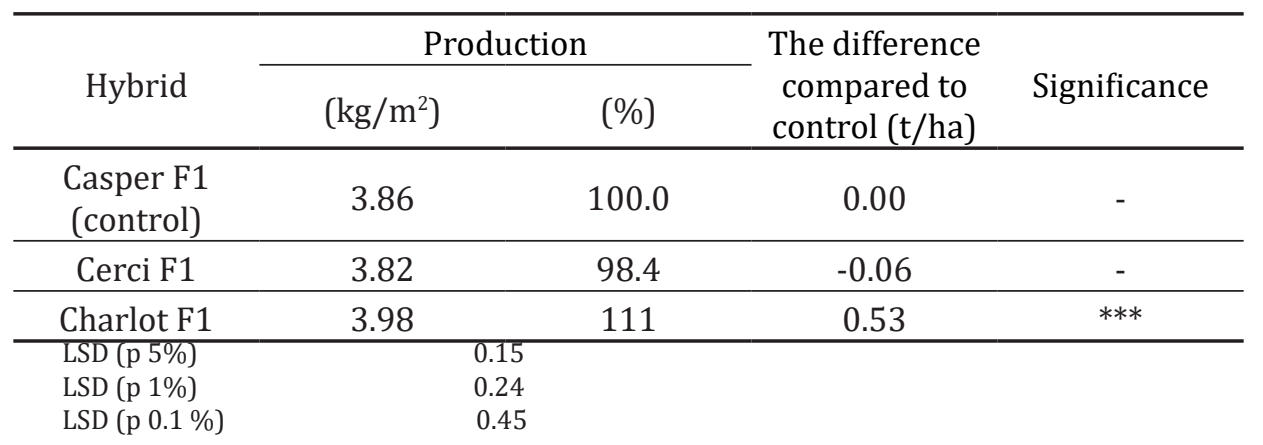

applied, whereas lower diameter $(17.18 \mathrm{~cm})$ was found in control condition, unfertilized (Elahi et al. 2015). Increasing curd diameter, higher plant vigor, increased number of leaves and higher production is a result of optimum fertilizer dose application and improved availability of plant nutrients in the soil (Elahi et al. 2015).

Surprisingly, the average cauliflower inflorescence weight was under the data provided by the seed producer. Low values regarding the weight of cauliflower inflorescences were recorded at 'Charlot' $\mathrm{F}_{1}$, unfertilized (V7), with a medium weight of $1.25 \mathrm{~kg}$ and 'Cerci' $\mathrm{F}_{1}$, unfertilized (V4) with a medium weight of $1,28 \mathrm{~kg}$ (Fig. 1). Highest values, of $1.54 \mathrm{~kg}$, was obtained at 'Charlot' $\mathrm{F}_{1}$ (V9), fertilized twice.

Regarding the unilateral influence of fertilization on the production of cauliflower grown in the field, it can be seen from table 2 that the number of fertilizations directly influences production. Production ranged from $3,59 \mathrm{~kg} /$ $\mathrm{m}^{2}$ at the unfertilized variant and $4.12 \mathrm{~kg} / \mathrm{m}^{2}$ recorded when culture was fertilized twice with $1 \mathrm{t} /$ ha Fulet. Inflorescence mass increased with fertilizers doses. The mass in this experiment was similar to that $(1,120 \mathrm{~g})$ reported by Monteiro et al. (2010) in work with Verona cultivar in an autumn experiment for the observation of cauliflower hybrids. The value obtained in this experiment where, however, larger than that reported by Pôrto et al. (2012) (860 g) in an experiment in which the plants were cultivated at the same population density.

Cauliflower productivity was observed to increase linearly with doses of fertilizers in other experiments conducted by other researchers, similar to the results obtained in this experiment.

When fertilizer was not applied, the inflorescence production was $3,35 \mathrm{~kg} / \mathrm{m}^{2}$, a value representing $79 \%$ of the maximum yield (Van Den Boogaard and Thorup-Kristensen, 1997) this value being lower than the one obtained in this experiment, $3,59 \mathrm{~kg} / \mathrm{m}^{2}$. 
Tab. 4. Combined influences of studied factors upon the production of cauliflower

\begin{tabular}{|c|c|c|c|c|}
\hline \multirow[b]{2}{*}{ Variant } & \multicolumn{2}{|c|}{ Production } & \multirow{2}{*}{$\begin{array}{l}\text { The difference } \\
\text { compared to } \\
\text { control (t/ha) }\end{array}$} & \multirow[b]{2}{*}{ Significance } \\
\hline & $\left(\mathrm{kg} / \mathrm{m}^{2}\right)$ & $(\%)$ & & \\
\hline V1 & 3.67 & 100.0 & 0.00 & - \\
\hline V2 & 3.87 & 105.4 & 0.20 & $*$ \\
\hline V3 & 4.06 & 110.6 & 0.39 & $* *$ \\
\hline $\mathrm{V} 4$ & 3.61 & 100.0 & 0.00 & - \\
\hline V5 & 3.88 & 107.4 & 0.27 & $* *$ \\
\hline V6 & 3.98 & 110.2 & 0.37 & $* *$ \\
\hline V7 & 3.50 & 100.0 & 0.00 & - \\
\hline V8 & 3.81 & 108.8 & 0.31 & $* *$ \\
\hline V9 & 4.33 & 123.7 & 0.83 & $* * *$ \\
\hline $\begin{array}{l}\text { LSD (p 5\%) } \\
\text { LSD (p 1\%) } \\
\text { LSD (p } 0.1 \%)\end{array}$ & & & & \\
\hline
\end{tabular}

Differences in production were distinct significant at the variants where one fertilization was done and very significant at the variants where two fertilizations were done, compared to the unfertilized variant, considered control.

Regarding hybrid influence upon production, as seen in table 3 , it can be said that the hybrid has a small influence upon production.

Average production had similar values in all hybrids with an increase in production of $11 \%$ in 'Charlot' F1.

Only statistically ensured production was obtained in 'Charlot' and it was significant positive compared to control.

Regarding the combined influence of the two factors (hybrid and number of fertilizations) on production it can be seen in table 4 , the lowest production of $3,50 \mathrm{~kg} / \mathrm{m}^{2}$ was obtained at variant V7 ('Charlot' unfertilized) and the highest production of $4,33 \mathrm{~kg} / \mathrm{m}^{2}$ was obtained at variant V9 ('Charlot' fertilized twice).

Fertilization and fertilization mode directly influences the production of cauliflower, regardless of the hybrid used.

Thus a single fertilization increased the production of all hybrids (V2, V5, V8). Variant V2 achieved a significant positive increase of production, statistically assured compared to control. Variant V5 achieved a distinct significant increase of production and V8 also achieved a distinct significant increase, differences being statistically assured.
Second fertilization application made a higher increase in production (at variants V3, V6, V9) compared to the others variants. Thus V3 and V6, obtained a distinct significant and positive increase in production. Highest production value was obtained at V9 and the increase in production was very distinct positive, differences being statistically assured.

Production obtained at cauliflower crops grown in open field in Apahida, near Cluj-Napoca, is influenced from all points of view by the number of applied fertilizations.

\section{CONCLUSIONS}

All hybrids reacted positively to additional fertilization. Vegetative growth was lower at the unfertilized variants and the largest vegetative growths were obtained at variants fertilized twice with $1 \mathrm{t}$ /ha Fulet.

Overall it can be said that 'Charlot' $F_{1}$ hybrid is the most vigorous from all of studied hybrids and 'Casper' $F_{1}$ is the less vigorous from the three.

In terms of inflorescences diameter, hybrid 'Casper' obtained the lowest value, of $16 \mathrm{~cm}$ at V1 and the highest value was obtained at 'Casper' $\mathrm{F}_{1}$ (V9) and it was of $21 \mathrm{~cm}$.

Regarding average inflorescences weight, the results showed that the hybrid 'Charlot' has obtained the lowest value of $1.25 \mathrm{~kg}$ (at V7) but also the highest value of $1.54 \mathrm{~kg}$ (at V9).

After this research, it can be recommended for autumn cauliflower crops grown in open field, 
hybrid 'Charlot', applying two fertilizations during the vegetation period.

\section{REFERENCES}

1. Apahidean AS, Apahidean AI (2016). Legumicultura Risoprint Publishing House, Cluj-Napoca, (pp. 162-164).

2. Bianco MS, Cecílio Filho AB, de Carvalho LB (2015). Nutritional Status of the Cauliflower Cultivar 'Verona'Grown with Omission of out Added Macronutrients. PloS one, 10(4), e0123500.

3. Cecílio Filho AB, da Silva ALP, Mendoza-Cortez JW, Barbosa JC (2015). Cauliflower and broccoli productivity as influenced by phosphorus fertilizer doses in a P-rich soil. Australian Journal of Crop Science, 9(8): 709.

4. Elahi E, Wali A, Ayub G, Ahmed S, Huma Z, Ahmed N (2015). Response of cauliflower (Brassica oleracea L. botrytis) cultivars to phosphorus levels. Pure and Applied Biology, 4(2): 187.

5. Gherghi A, Burzo I, Bibicu M, Mărgineanu L, Bădulescu L (2002). Biochimia şi fiziologia legumelor şi fructelor. Romanian Academy Publishing House, Bucharest (pp. 8586).

6. Klastorf Romania (2017). http://www.klastorf.ro/detaliiproduse/ProductsCatalog-Product/10033-GUANITO-6N---15-P205---3-K20-/6631-Ingrasaminte-organice.

7. Mohanty, S., Srivastava, B.K. (2002). Effect of time of planting and method of crop raising on seed production of Pant Shubhra midseason cauliflower (Brassica oleracea, var botryitis, subv.cauliflora L). Indian Journal of Agricultural Sciences, 72(11): 682-684.
8. Monteiro BCB, Charlo HC, Braz LT (2010). Desempenho de híbridos de couve-flor de verao em Jaboticabal. Horticultura Brasileira 28: 115-119.

9. Pôrto DRQ Filho AB, Rezende BLA, Barros Júnior AP, Silva GS (2012). Densidade populacional e época de plantio no crescimento e produtividade da couve-flor cv. Verona 284. Revista Caatinga 25: 92-98.

10. Prohens J, Nuez F (2008). Vegetables, Asteraceae, Brassicaceae, Chenopodiaceae and Cucurbitaceae. Handbook of Plant Breeding, Vol.1, Springer, New York 42-43.

11. Quirós R, Villalba G, Munoz P, Font X, Gabarrell X (2014). Environmental and agronomical assessment of three fertilization treatments applied in horticultural open field crops. Journal of Cleaner Production, 67: 147-158.

12. Silva AP, Filho AB, Mendoza-Cortez JW, Lima Junior JA (2016). Potassium fertilization of cauliflower and broccoli in a potassium-rich soil, Cienc. Inv. Agr. vol.43 no.1 Santiago abr.

13. Singh R, Chaurasia SNS, Singh SN (2006). Response of nutrient sources and spacing on growth and yield of broccoli (Brassica oleracea var. italic Pleuch). Indian Institute of Vegetable Research,Vegetable Science, v. 33, n. 2 (pp. 198-200).

14. Van Den Boogaard R, Thorup-Kristensen K (1997). Effects of nitrogen fertilization on growth and soil nitrogen depletion in cauliflower. Acta Agriculturae Scandinavica B-Plant Soil Sciences, 47(3): 149-155. 